\title{
Problem-based Learning in a Supply Chain Management Course
}

\section{Dr. Ekaterina Koromyslova, South Dakota State University}

Ekaterina Koromyslova is an Assistant Professor in Operations Management at South Dakota State University. She holds PhD in Economics and two MS degrees in Business Economics and Operations Management. She has over five years of college teaching work experience in Operations Management and Supply Chain Management fields. Her industry experience is an analyst-consultant in business processes improvement area for manufacturing companies and a deputy head of a customer service department in a leading 3PL full service logistics company in the Russian and CIS logistics market.

\section{Prof. Byron G. Garry, South Dakota State University}

BYRON GARRY is an Associate Professor and Undergraduate Program Coordinator in the Department of Construction \& Operations Management in the College of Engineering at South Dakota State University. 


\title{
Problem-Based Learning in a Supply Chain Management Course
}

\begin{abstract}
The paper illustrates different applications of problem-based learning in junior/senior level Supply Chain Management (SCM) course and the effect of the problem-based learning environment on achieving students learning objective for the course. Sipes' Problem-Based Curriculum Matrix, which combines Barrows' Taxonomy of teaching methods with Jonassen's Problem Typology, was used as a tool. The tool helps enumerate the different types of problembased learning (PBL) techniques that were used in the course. The tool illustrated that the course used more PBL the second time it was taught. Outcomes of teaching the SCM course in two semesters were compared by class average grade, grade distribution, students' perception of the level of challenge in their work on a design project, and IDEA teaching evaluation scores from students. The paper will explain the process used and show the results from the first and second time the course was taught.
\end{abstract}

\section{Keywords}

Problem-Based Learning, Supply Chain Management

\section{Introduction}

In the senior year of the South Dakota State University (SDSU) Operations Management program, students take a Supply Chain Management (SCM) course. One of the Student Learning Outcomes goals for the course is stated as "Students will demonstrate ability to apply analytics methodologies, utilizing practical managerial levers, to achieve competitive advantage in the supply chain". We chose this as a Student Learning Outcome because it is the main thrust of the course, that graduates will be able to start in their first industry position and immediately contribute to the success of the supply chain process for that business. As has been seen in industry, as well as in academia, what gets measured often gets improved ${ }^{1}$.

\section{Problem Based Learning}

To assure that students can apply the knowledge and skills we want them to achieve, we know that we cannot teach in the course in standard lecture style, and must use various forms of active learning in the course. Felder ${ }^{2}$, et al., found in a review of literature that when the objective of learning is to facilitate long-term retention of information, or to help the students develop or improve their problem-solving or thinking skills, instruction that involves students actively has consistently been found more effective than straight lecturing. Specifically, we have chosen to approach the course as an exercise in problem-based learning (PBL).

Prince and Felder ${ }^{3}$ define PBL as "students have not previously received formal instruction in the necessary background material and the solution process is more important than the final product." 
Barrows ${ }^{4}$, doing research in the medical education field in the 1980's, stated that problem-based learning can have many different meanings, depending on the skills of the teacher and the educational learning objectives being pursued. In the medical field, existing cases taken from the medical research literature are an important part of the educational process. Barrows saw that a taxonomy was needed to help differentiate the many types of case-based learning processes possible. The taxonomy ranges from cases explained mostly via lecture, through looking at a case from beginning to end, applying lessons learned, and starting back at the beginning of the case again, to see is a different approach to the case is called for. Barrows listed the taxonomy as

- Traditional lecture-based cases

- Case-based lecture

- Case method

- Modified case-based

- Problem-based

- Closed-loop problem based

Jonassen $^{5}$ suggests looking at problem-based learning in a different way, as a range of different types that exist on a continuum ranging from well-structured to ill-structured. This typology includes the following eight problem types: story problems, rule-using problems, decisionmaking problems, troubleshooting problems, strategic performance problems, policy problems, design problems, and dilemmas. It is the ill-structured problems that are theorized to be better suited to PBL.

Dochy, et al. ${ }^{6}$ examined 43 empirical studies investigating how PBL impacts students' knowledge and skills. They found that PBL is more effective than traditional forms of instruction in developing students' skills, which is what this SCM course is aimed at. The meta-study did find that students in a problem-based learning environment tended to exhibit slightly less knowledge overall, but remembered more of the knowledge they gained during their learning experience, than did students in a traditional learning environment.

\section{PBL Applied to a Supply Chain Management Course}

In this paper we evaluate the impact of problem based learning, an active learning technique, on achievement of student learning outcomes in the Supply Chain Management course. It is a junior/senior level course of the Operations Management undergraduate program. There are four learning objectives defined in this course: After successful completion of the course, students should be able to:

1) Differentiate and explain the concept, framework, and techniques of the supply chain design, planning, operation, and strategic management. (ASAC j)

2) Apply analytic methodologies, utilizing practical managerial levers, to design a supply chain for defined conditions, and to achieve competitive advantage in the supply chain. $(\mathrm{ASAC} 1)$

3) Analyze contemporary issues in SCM and to propose solutions to the identified issues. (ASAC m) 
4) Demonstrate an ability to communicate effectively and use information from a variety of sources. (ASAC g)

The notation of (ASAC $\mathrm{x}$ ) after each learning objective shows how, as a part of our ABET$\mathrm{ASAC}^{7}$ student outcome continuous improvement process, the course learning objective is tied to specific ABET Student Outcome (the SDSU OM program defines Student Outcomes as (a) (m)):

- $\operatorname{ASAC}(\mathrm{g})$ an ability to communicate effectively and use information from a variety of sources

- $\quad A S A C(j)$ a knowledge of contemporary issues

- ASAC (1) an understanding of management theory and practice, including the strategic planning process, project management, and personal and organizational goal setting

- $\quad \mathrm{ASAC} \mathrm{m}$ ) an understanding of leveraging resources, quality management theory and practice, and the ability to use these tools effectively in the workplace

The course has been taught twice with a different set of PBL techniques each semester, in Fall 2014 and in Fall 2015. There were 18 students in the first semester and 21 students in the second semester in the supply chain management class.

To achieve the course learning objectives 2, 3, and 4 students are required to work on a project during the semester. The goal of the project is to design a domestic supply chain for a manufacturing company. Whole class works as a Shoes Manufacturing Company which produces Oxford men shoes in the United States. There are five departments in the company with 3-4 students-employees: Sales and Customer Relationship department, Manufacturing department, Procurement department, Logistics department, and Management and Administration department. One person from each department is a leader (Department Head); one person is CEO of the company. The class is provided with basic input information required for the design, such as demand forecast, specification, bill of materials, material requirements, cutting waste, labor time, and the company operating time. The project guidelines reflect illstructured problem based approach with relaxed framework and freedom for performance. Only one written report is required from whole class. Oral presentation of the project should be given at the end of semester (one from whole class). Each group (department) is responsible for the report section related to the department's activity, and for integration of all sections together into one report. The final report consists of three parts:

1) Theoretical part of the project is a research and benchmarking part. Students are required to conduct literature review on given topic to examine existing systems/methods/practices and to support (justify) choice of one of them for the designed supply chain. The literature review should consist of 5-10 sources, and include examples of other companies in the industry.

2) Collaborative part of the project requires collaboration with other departments. This part includes supply chain strategy and performance metrics, supply chain configuration, and planning. 
3) Analytical part of the project should include justification of particular systems/methods chosen for the designed supply chain, and necessary calculations.

There are three milestones for this project during a semester. Students have to submit specified part of the project at each intermediate deadline. The instructor provides feedback on submitted material. After that students are allowed to make any corrections or additions to the project report. Also, instructor's feedback is provided for the final draft of the project, and students are able to make changes before the final submission and the oral presentation.

The project was assigned in both semesters, but other teaching techniques and active learning activities were different in these two semesters. In Fall 2014 the main teaching methods besides the project were lectures/lecture-based cases, and case-based lectures. Case method was used once during the semester (Table 1). In Fall 2015 less time was allocated for the lecture-based cases. Decision-making and troubleshooting types of problems ${ }^{2}$ were worked out using casebased lecture approach. Strategic Performance and Policy problems were addressed via Case method and Modified case-based method (Table 2). Inductive teaching technique was applied at these level of Barrows taxonomy, as Prince and Felder ${ }^{9}$ define them, where students were asked to read material before class, and were challenged with a case at the beginning of a class session. During the class session they brainstormed ideas, searched for necessary information, discussed, and developed a solution to the case. The instructor facilitated the process and assisted in summarizing of the results and connecting them to the particular concept of the course. Another example is online simulation games and exercises. For online exercises, students played the same game two times during a class session: before discussion of the related concept and theoretical aspects of it, and after that with the opportunity to apply learned material. Then results of both trials were compared. The second trial results (e.g., profit) were always better, and students felt that they have proven for themselves that:

- they learned the new material,

- they were able to apply this knowledge to the real-world situation, and

- they produced a better solution (outcome) the second time.

This inductive teaching/learning approach helps to motivate students and to develop their confidence that they are capable and competent in this area. This was a good foundation for their readiness and preparedness to the design project. The final online simulation game (two consequent class sessions) was offered to students at the end of the second semester. This game integrates all concepts and applications of supply chain management. Students appreciated the game as an opportunity to apply all learned material and demonstrated good results. It improved their self-esteem again before giving the final oral presentation of the design project.

Thus, introduction of new additional active learning techniques throughout the all levels of Barrows taxonomy ${ }^{4}$ allowed the instructor to create smooth flow of teaching-learning approaches for the course. As a result, students were better prepared for the problem-based type of assignment; they felt more comfortable in the active learning and problem-based learning 
environment; they were more motivated and engaged in the learning process, and they developed confidence in their capabilities.

A Problem-Based Curriculum Matrix developed by Sipes $^{8}$ was used as a tool for comparison of the impact of different sets of active learning, mostly problem-based, techniques on student learning outcomes. The matrix combines Barrows' Taxonomy of teaching methods ${ }^{4}$ with Jonassen's Problem Typology ${ }^{5}$. The total curriculum $\mathrm{PBL}^{8}$ environment scores were computed and compared for two semesters of teaching the SCM course.

From $\operatorname{Sipes}^{8}$, the PBL Matrix score is generated by looking at all teaching materials used throughout the semester. For this course the faculty member generated nine sets of course notes and PowerPoints, many of which covered more than one class session. The course notes were provided to the students through the university's course management system (D2L), and they had access to them before class to print out, or to follow along on a laptop during class time. The course notes contain titles and highlights of the in-class material, but were mostly blank to provide students a place to record notes and record their problem-based group work.

After the semester was complete, the faculty member, and another faculty member as an outside check, reviewed the materials independently. Each time there was a student prompt in the course notes or notation on a PowerPoint that matched a place in the matrix, a check was placed in the matrix. Sipes' work proposes a point score for each type of teaching/learning behavior, with the scores increasing as more complex problem-based learning is implemented.

On the vertical axis (Barrow's Taxonomy ${ }^{4}$ ), the scores ranged from 3 points for a traditional lecture-based case to 20 points for a Closed-Loop Problem Based case. On the horizontal axis (Jonassen's Problem Type ${ }^{5}$ ), the scores ranged from 1 point for a story problem to 8 points for a dilemma problem. The score in each box of the matrix is generated by multiplying the horizontal and vertical scores.

For example, from the top row of the 2014 Matrix (Table 1), it was noted that at some time in the semester that there was an instance of using:

- A Lecture-based Rule-Using Problem (6 points)

- A Lecture-based Decision-Making Problem (9 points)

- A Lecture-Based Troubleshooting Problem (12 points)

The scores in each box in the matrix are added together to produce a total PBL score. This scoring was done only after the course instructor had completed the two semesters of the course, and then reviewed the course notes/PowerPoints provided to the students.

The calculation of the teaching methods for both semesters is presented in Table 1 and Table 2 . Total course PBL environment score is calculated for Fall 2014 (824) and for Fall 2015 (1074). The score is higher by $30 \%$ in the second semester of teaching the supply chain management course. 


\begin{tabular}{|c|c|c|c|c|c|c|c|c|c|c|}
\hline & \multicolumn{9}{|c|}{ Jonassen's Problem Type } \\
\hline & & $\begin{array}{c}\text { Story } \\
\text { Problems } \\
(1) \\
\end{array}$ & $\begin{array}{c}\text { Rule-Using } \\
\text { Problems } \\
(2) \\
\end{array}$ & $\begin{array}{c}\text { Decision- } \\
\text { Making } \\
\text { Problems } \\
\text { (3) }\end{array}$ & $\begin{array}{c}\text { Troublesho } \\
\text { oting } \\
\text { Problems } \\
(4) \\
\end{array}$ & $\begin{array}{c}\text { Strategic } \\
\text { Performance } \\
\text { Problems } \\
(5) \\
\end{array}$ & $\begin{array}{c}\text { Policy } \\
\text { Problems } \\
(6) \\
\end{array}$ & $\begin{array}{c}\text { Design } \\
\text { Problems } \\
(7) \\
\end{array}$ & $\begin{array}{c}\text { Dilemmas } \\
\text { (8) } \\
\end{array}$ & $\begin{array}{c}\text { Total } \\
\text { Taxonomy } \\
\text { Type }\end{array}$ \\
\hline \multirow{7}{*}{ 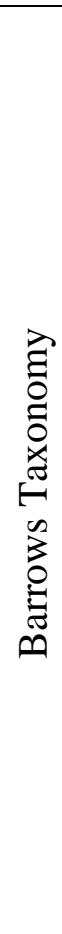 } & $\begin{array}{l}\text { Lecture-Based } \\
\text { Cases (3) }\end{array}$ & & 6 & 9 & 12 & & & & & 27 \\
\hline & $\begin{array}{l}\text { Case-Based } \\
\text { Lecture (6) }\end{array}$ & & & & & 30 & 36 & & & 66 \\
\hline & $\begin{array}{l}\text { Case Method } \\
\text { (13) }\end{array}$ & & & & & 65 & & & & 65 \\
\hline & $\begin{array}{l}\text { Modified Case- } \\
\text { Based } \\
\text { (15) }\end{array}$ & & & & & & & & & 0 \\
\hline & $\begin{array}{l}\text { Problem-Based } \\
\text { (17) }\end{array}$ & & & & & 85 & 102 & 119 & & 306 \\
\hline & $\begin{array}{l}\text { Closed-Loop } \\
\text { Problem Based } \\
\text { (20) }\end{array}$ & & & & & 100 & 120 & 140 & & 360 \\
\hline & $\begin{array}{l}\text { Total Problem } \\
\text { Type }\end{array}$ & 0 & 6 & 9 & 12 & 280 & 258 & 399 & 0 & 824 \\
\hline
\end{tabular}

Table 1. Problem-Based Learning Curriculum Matrix Fall 2014 


\begin{tabular}{|c|c|c|c|c|c|c|c|c|c|c|}
\hline & \multicolumn{9}{|c|}{ Jonassen's Problem Type } \\
\hline & & $\begin{array}{c}\text { Story } \\
\text { Problems } \\
(1) \\
\end{array}$ & $\begin{array}{c}\text { Rule-Using } \\
\text { Problems } \\
(2) \\
\end{array}$ & $\begin{array}{c}\text { Decision- } \\
\text { Making } \\
\text { Problems } \\
\text { (3) }\end{array}$ & $\begin{array}{c}\text { Troublesho } \\
\text { oting } \\
\text { Problems } \\
(4) \\
\end{array}$ & $\begin{array}{c}\text { Strategic } \\
\text { Performance } \\
\text { Problems } \\
(5) \\
\end{array}$ & $\begin{array}{c}\text { Policy } \\
\text { Problems } \\
(6) \\
\end{array}$ & $\begin{array}{c}\text { Design } \\
\text { Problems } \\
(7) \\
\end{array}$ & $\begin{array}{c}\text { Dilemmas } \\
\text { (8) }\end{array}$ & $\begin{array}{c}\text { Total } \\
\text { Taxonomy } \\
\text { Type }\end{array}$ \\
\hline \multirow{7}{*}{ 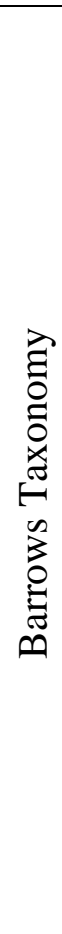 } & $\begin{array}{l}\text { Lecture-Based } \\
\text { Cases (3) }\end{array}$ & & 6 & & & & & & & 6 \\
\hline & $\begin{array}{l}\text { Case-Based } \\
\text { Lecture (6) }\end{array}$ & & & 18 & 24 & & & & & 42 \\
\hline & $\begin{array}{l}\text { Case Method } \\
\text { (13) }\end{array}$ & & & & 52 & 65 & 78 & & & 195 \\
\hline & $\begin{array}{l}\text { Modified Case- } \\
\text { Based } \\
\text { (15) }\end{array}$ & & & & & 75 & 90 & & & 165 \\
\hline & $\begin{array}{l}\text { Problem-Based } \\
\text { (17) }\end{array}$ & & & & & 85 & 102 & 119 & & 306 \\
\hline & $\begin{array}{l}\text { Closed-Loop } \\
\text { Problem Based } \\
\text { (20) }\end{array}$ & & & & & 100 & 120 & 140 & & 360 \\
\hline & $\begin{array}{l}\text { Total Problem } \\
\text { Type }\end{array}$ & 0 & 6 & 18 & 76 & 325 & 390 & 259 & 0 & 1074 \\
\hline
\end{tabular}

Table 2. Problem-Based Learning Curriculum Matrix Fall 2015 


\section{Improvements in Student Learning}

The following four Metrics were used to compare outcomes of teaching the SCM course in these two semesters:

1) Class average grade

2) Grade distribution

3) Students' perception of the level of challenge in their work on a design project, and

4) IDEA teaching evaluation scores from students.

For Metric \#1, the Class average grades were 82 (out of 100) in Fall 2014, and 83 in Fall 2015, which do not show a major difference.

For Metric \#2, however, the grade distributions (90\% and above = A, $80 \%$ and above = B, etc.), shown in Fig. 1, are different in Fall 2014 and Fall 2015.

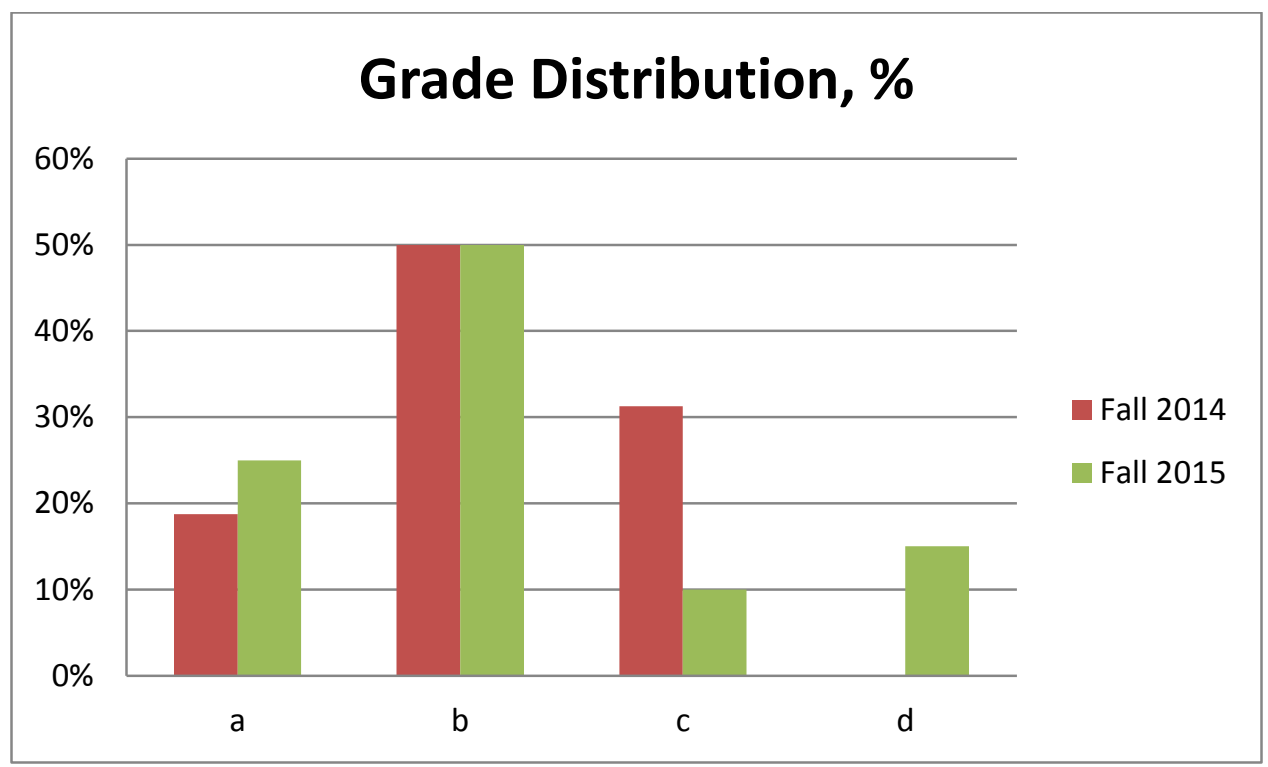

Figure 1. Students grade distribution

After introduction of additional active learning, problem-based techniques, the percentage of A grades increased from $19 \%$ to $25 \%$, the percentage of B grades did not change, but the C level broke down into two parts: $\mathrm{C}$ and $\mathrm{D}$. Thus, as a result, more students received $\mathrm{A}$ and $\mathrm{B}$ grades in the second semester (75\% vs. $69 \%$ in the first semester). Also, the grading was more précised with incorporation of greater variety of teaching methods and assessment instruments in terms of differentiation of C-region students into two categories and discovering gaps in their progress on learning objectives.

At the end of each semester, when the supply chain design project was complete, the instructor applied Metric 3, asking the students what was the level of challenge for them in their work on the project for nine different factors, using a scale from $0=$ no challenge at all, to $10=$ the greatest challenge. The average level of challenge based on students' perception is shown in Figure 2. 


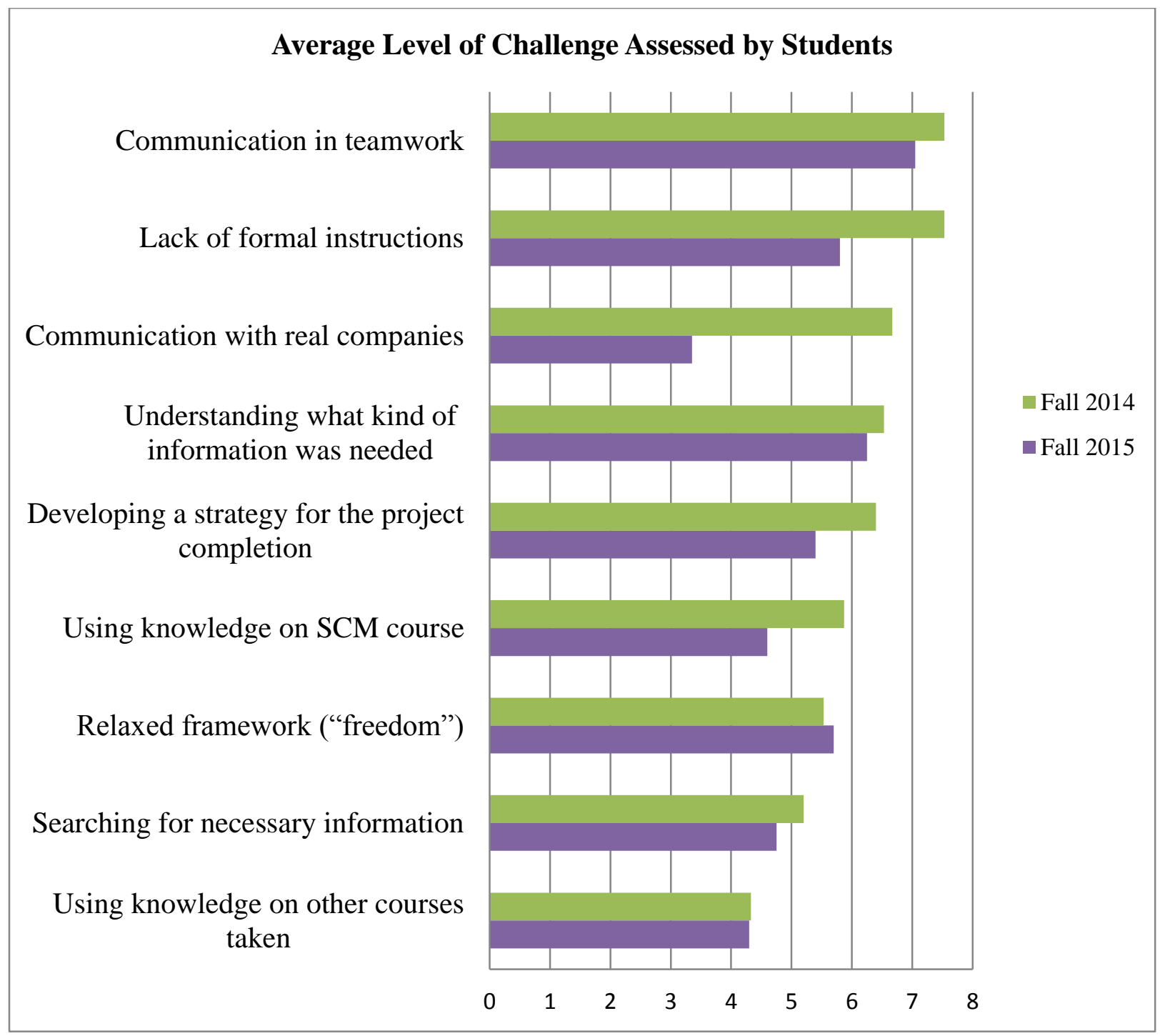

Figure 2. Average level of challenge in scale $0-10$ (10 is the highest level)

In Fall 2014 the major challenges for students were 'communication in teamwork', 'lack of formal instructions', and 'communication with real companies'. The least challenging was 'using knowledge on other courses taken'. In Fall 2015, the challenge level decreased for almost all factors listed. Interesting, that no significant difference was observed in the challenge of using curricular knowledge from other courses, but at the same time, using knowledge on SCM course became less challenging in the second semester. Communication in teamwork was still top challenging factor (7.53 and 7.05 in 2014 and 2015 accordingly), but students felt much more comfortable in communication with real companies (6.67 vs. 3.35) and working with minimum of formal instructions on the project (7.53 vs. 5.80). Dealing with information and developing an approach to the project were less difficult in the second semester, although the relaxed 
framework of the problem-based approach was still perceived as 'undesired freedom'. The results of this survey on students' perceived level of challenge allow us to conclude that the set of problem-based techniques used in the second semester produced better results in achieving the course learning objectives.

For Metric \#4, IDEA teaching evaluation scores, also supported the conclusion that in Fall 2015 students achieved better results in the SCM class.

The course learning objectives and ABET-ASAC criteria are also tied to questions asked of students in the course-ending faculty assessment done by the students, using the Individual Development and Educational Assessment ${ }^{5}$ (IDEA) form. The IDEA presents students with twelve general learning objectives, such as 'I gained factual knowledge', that students answer on a 1 - 5 scale, with 5 being Strongly Agree to 1 Strongly Disagree. As a part of our ABET-ASAC continuous improvement process, we correlated IDEA general statements to ABET-ASAC student outcome statements. This allows the faculty to more closely tie together the student opinion of how well they learned with the results of grading done by the faculty on homework, reports, tests, and presentations. See Appendix A for a summary of these correlations in the supply chain management course.

The results of IDEA evaluations are shown in Fig. 3 and Fig. 4.

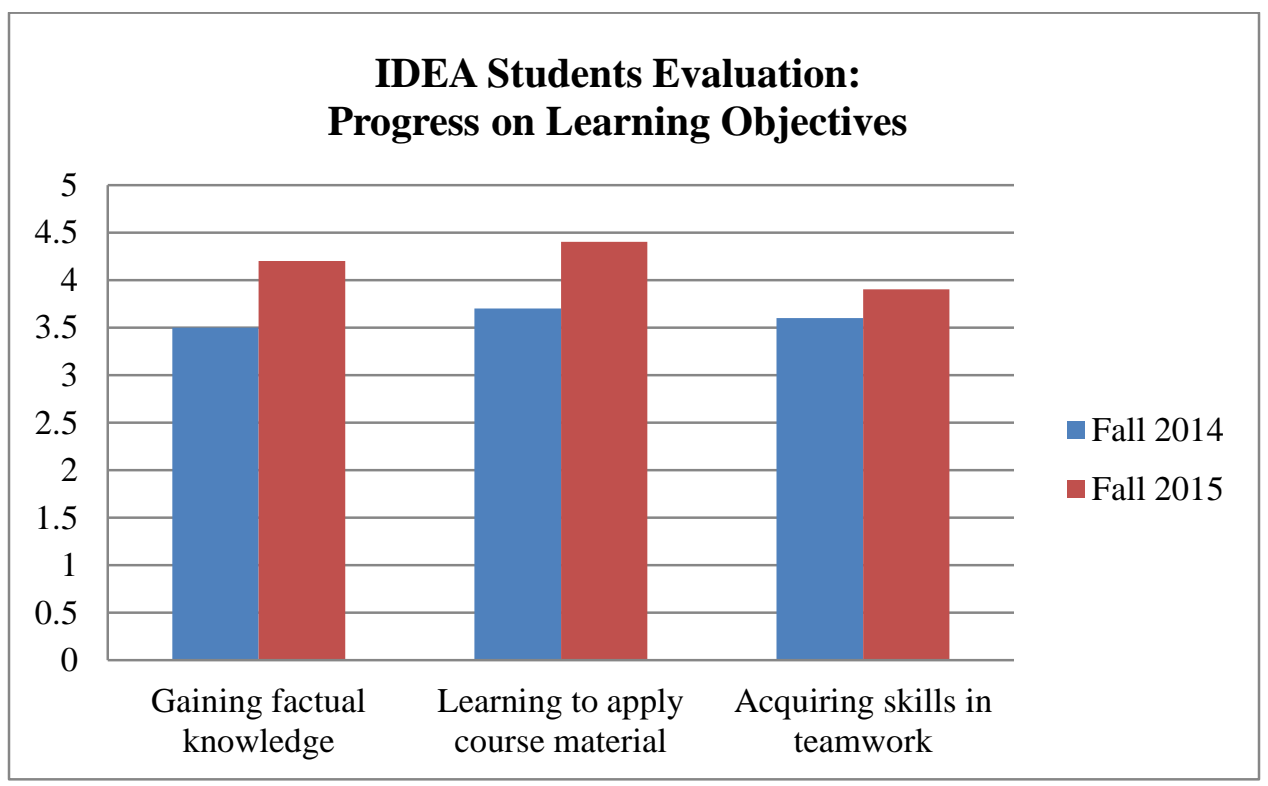

Figure 3. IDEA scores: students' progress on learning objectives

Students demonstrated growth on three major learning objectives in Fall 2015 in comparison with Fall 2014. Progress on gaining factual knowledge increased by $20 \%$ (from 3.5 to 4.2 ), learning to apply course material improved by $19 \%$ (from 3.7 to 4.4), and acquiring skills in working with others raised by $8 \%$ (Fig. 2). Average progress on relevant learning objectives was higher by $17 \%$ (Fig.3). For 'excellent teacher' and 'excellent course' scores were also higher, by 
$37 \%$ and $27 \%$ accordingly. Summary score growth was $21 \%$ with application with the higher PBL score for the course (Fig. 4).

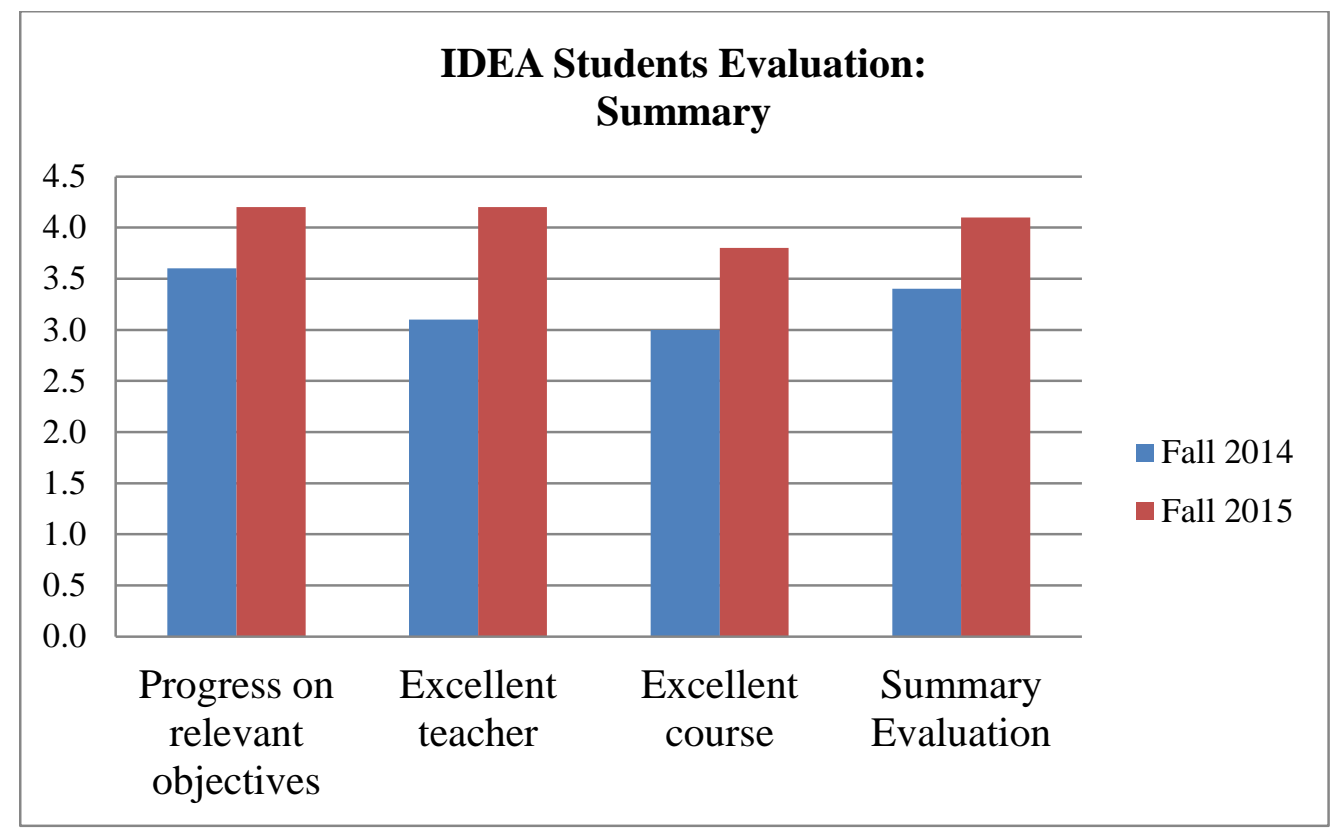

Figure 4. IDEA scores summary

Thus, all metrics confirmed that more intense problem-based environment provides better learning opportunities for students, supports the development of their competence in the course material, and increases their confidence as professionals in the field. More accurate results could have been achieved with a pre-test at the start of the course to better assess the students' level of improvement, but that was not done the two times the course was taught.

\section{Conclusion}

In Fall 2014, the course instructor was using several active learning methods, including problembased learning, as seen by a PBL Matrix score of 824. In Fall 2015, the instructor adopted more problem-based methods, resulting in a PBL Matrix score of 1074. The most important changes were the shift of the instructional method from lecture-based cases toward a case-based method, and filling the gap in the taxonomy of active learning methods by introducing case method and modified case method to address a broader range of problem types. It was an additional training for students to work in the problem-based student-centered environment, like a bridge between theory and real-world business situations. They were getting used to this type of assignments, and better understood instructor's expectations.

So, we can conclude that the higher PBL environment score is better for student learning outcomes and for achieving the course learning objectives, but it is very important to define right amount/set of active learning techniques as well as to maintain smooth flow though the taxonomy/problem types without gaps in the flow. Among other active learning techniques, inductive teaching approach works better for developing of students' motivation, competence 
and confidence, which are critical for this type of course as the Supply Chain Management course.

\section{References}

1. National Academy of Engineering. 2009. Developing Metrics for Assessing Engineering Instruction: What Gets Measured is What Gets Improved. Report from the Steering Committee for Evaluating Instructional Scholarship in Engineering. Retrieved from http://www.nae.edu/Projects/CASEE/61339/24846.aspx

2. Felder, R.M., Woods, D.R., Stice, J.E. \& Rugarcia, A. 2000. The Future of Engineering Education II. Teaching Methods that Work. Chemical Engineering Education 34(1).

3. Prince, M \& Felder, R. 2007. The Many Faces of Inductive Teaching and Learning, Journal of College Science Teaching. 36(5).

4. Barrows, H. S. 1986. A taxonomy of problem-based learning methods. Medical Education, 20(6), 481-486.

5. Jonassen, D. H. 2000. Toward a design theory of problem solving. Educational Technology Research and Development, 48(4), 63-85.

6. Dochy, F., Segers, M., Van den Bossche, P., \& Gijbels, D. 2003. Effects of problem-based learning: A meta-analysis. Learning and Instruction, 13(5), 533-568.

7. ABET. 2016-17 Criteria for Accrediting Applied Science Programs. Baltimore, MD. Retrieved from http://www.abet.org/accreditation/accreditation-criteria/criteria-for-accrediting-applied-scienceprograms-2016-2017/

8. Sipes, S. M. 2015. Impact of problem-based learning on engineering student curiosity development (Order No. 3717477). Available from ProQuest Dissertations \& Theses Global. (1711733517). Retrieved from http://search.proquest.com/docview/1711733517?accountid=28594

9. Prince, M.J. \& Felder, R.M. 2006. Inductive teaching and learning methods: Definitions, comparisons, and research bases, Journal of Engineering Education, 95(2): 1-16.

10. IDEA website. 2016. Retrieved from http://ideaedu.org/ 


\section{Appendix A.}

Individual Development and Educational Assessment ${ }^{2}$ (IDEA) feedback system was used to assess teaching and learning in the course. Correlation of the course learning objectives, IDEA learning objectives and ABET-ASAC criteria is shown in Table 3.

\begin{tabular}{|c|c|c|c|}
\hline \multicolumn{2}{|r|}{ Course learning objectives } & $\begin{array}{l}\text { IDEA learning } \\
\text { objectives }\end{array}$ & $\begin{array}{l}\text { ABET-ASAC criteria } \\
\text { Students Outcomes }\end{array}$ \\
\hline 1 & $\begin{array}{l}\text { Differentiate and explain the } \\
\text { concept, framework, and } \\
\text { techniques of the supply chain } \\
\text { design, planning, operation, } \\
\text { and strategic management. }\end{array}$ & $\begin{array}{l}\text { Gaining factual } \\
\text { knowledge }\end{array}$ & $\begin{array}{l}\text { (1) an understanding of } \\
\text { management theory and } \\
\text { practice, including the } \\
\text { strategic planning process, } \\
\text { project management, and } \\
\text { personal and organizational } \\
\text { goal setting }\end{array}$ \\
\hline 2 & $\begin{array}{l}\text { Apply analytic methodologies, } \\
\text { utilizing practical managerial } \\
\text { levers, to design a supply chain } \\
\text { for defined conditions, and to } \\
\text { achieve competitive advantage } \\
\text { in the supply chain. }\end{array}$ & $\begin{array}{l}\text { Learning to apply } \\
\text { course material }\end{array}$ & $\begin{array}{l}(\mathrm{m}) \text { an understanding of } \\
\text { leveraging resources, quality } \\
\text { management theory and } \\
\text { practice, and the ability to use } \\
\text { these tools effectively in the } \\
\text { workplace }\end{array}$ \\
\hline 3 & $\begin{array}{l}\text { Analyze contemporary issues } \\
\text { in SCM and to propose } \\
\text { solutions to the identified } \\
\text { issues. }\end{array}$ & $\begin{array}{l}\text { Learning to apply } \\
\text { course material }\end{array}$ & $\begin{array}{l}\text { (j) a knowledge of } \\
\text { contemporary issues }\end{array}$ \\
\hline 4 & $\begin{array}{l}\text { Demonstrate an ability to } \\
\text { communicate effectively and } \\
\text { use information from a variety } \\
\text { of sources. }\end{array}$ & $\begin{array}{l}\text { Acquiring skills in } \\
\text { working with others } \\
\text { as a member of a } \\
\text { team; } \\
\text { Learning how to find } \\
\text { and use resources }\end{array}$ & $\begin{array}{l}\text { (g) an ability to communicate } \\
\text { effectively and use } \\
\text { information from a variety of } \\
\text { sources }\end{array}$ \\
\hline
\end{tabular}

Table 3. Correlation of the course learning objectives, IDEA learning objectives, and ABETASAC Student Outcome criteria 